\title{
Hygienic quality, lipolysis and sensory properties of Spanish Protected Designation of Origin ewe's milk cheeses manufactured with lamb rennet paste
}

\author{
Iñaki ETAYOa, Francisco José PÉREZ ELORTONDO ${ }^{a *}$, Pilar F. GIL ${ }^{\mathrm{a}}$, \\ Marta ALBISUa, Mailo VIRTO ${ }^{b}$, Socorro CONDE ${ }^{b}$, \\ Luis Javier RODRIGUEZ BARRON ${ }^{\mathrm{*} * *}$, Ana Isabel NÁJERA ${ }^{\mathrm{c}}$, \\ Maria Elena GÓMEZ-HIDALGO ${ }^{c}$, Cristina DELGADO ${ }^{\mathrm{d}}$, Angel GUERRA $^{\mathrm{d}}$, \\ Mertxe DE RENOBALES ${ }^{b * *}$ \\ a Nutrición y Bromatología, Universidad del País Vasco (UPV/EHU), Facultad de Farmacia, \\ Paseo de la Universidad 7, 01006 Vitoria-Gasteiz, Spain
b Bioquímica y Biología Molecular, Universidad del País Vasco (UPV/EHU), Facultad de Farmacia, \\ Paseo de la Universidad 7, 01006 Vitoria-Gasteiz, Spain \\ c Tecnología de Alimentos, Euskal Herriko Unibertsitatea, Universidad del País Vasco (UPV/EHU), \\ Facultad de Farmacia, Paseo de la Universidad 7, 01006 Vitoria-Gasteiz, Spain \\ d Cuajos Caporal S.L., Calle Roble - Nave 7, Polígono Industrial La Mora, 47193 La Cistérniga, \\ Valladolid, Spain
}

Received 7 July 2006 - Accepted 23 October 2006

\begin{abstract}
A lamb rennet paste preparation was studied to determine its suitability for the manufacture of the three main Spanish raw ewe's milk cheeses with Protected Designation of Origin (Manchego, Idiazabal and Zamorano) from the hygienic and sensory points of view. Cheeses were manufactured with lamb rennet paste or with commercial rennets (bovine powder rennet for Manchego cheese and liquid lamb rennet for Zamorano and Idiazabal cheeses) at identical levels of coagulating strength. Free fatty acids and partial glycerides were also analysed to study lipolysis levels and to relate them to sensory properties. No statistically significant differences were detected in microbiological counts for any of the species analysed between cheeses manufactured with lamb rennet paste and cheeses manufactured with non-paste commercial rennet. We conclude that the hygienic quality of the cheeses made in this study with lamb rennet paste was comparable with that of cheeses made with non-paste commercial rennet. Cheeses made with lamb rennet paste showed a higher lipolysis level than cheeses made with non-paste commercial rennet. Sensory differences between cheeses made with either type of rennet were mainly detected in Idiazabal cheese, whereas the sensory profile of the cheeses made with lamb rennet paste or with non-paste commercial rennet was rather similar for Manchego and Zamorano cheeses. Idiazabal cheeses manufactured with lamb rennet paste showed the highest scores for odour and flavour intensities, sharp odour, rennet odour and flavour, butyric flavour and pungent character. On the other hand, Idiazabal cheeses made with non-paste commercial rennet had higher scores for milk and buttery odour attributes than cheeses made with lamb rennet paste.
\end{abstract}

lamb rennet paste / cheese / ewe's milk / lipolysis / hygienic quality / sensory properties

\footnotetext{
* Corresponding author (通讯作者): franciscojose.perez@ehu.es

** Co-corresponding authors: mertxe.derenobales@ehu.es; luisjavier.rbarron@ehu.es
} 
摘要 - 膏状小羊凝乳酶生产的西班牙原产地命名保护绵羊奶干酪的卫生质量、脂肪水解和 感官性质的研究。本文基于王酪产品的卫生质量和感官特性系统地研究了手工制作的亳状 小羊凝乳酶是否适合于生产三种西班牙原产地命名保护的绵羊奶干酪。在 Manchego, Idiazabal 和 Zamorano 三种绵羊奶干酪制作中分别采用手工制作的膏状小羊凝乳酶和非亮状 的商业凝乳酶凝乳。根据分析产品中游离脂肪酸和部分甘油酯的含量来评价干酪中脂肪的 水解程度, 并进一步评价了对应产品的感官特性。由膏状凝乳酶和商业凝乳酶生产的三种 干酪在细菌总数上没有显著性的差异，但是由前者生产的干酪中脂肪水解程度高于后者。 由两种酶制造出的 Manchego 和Zamorano 干酪在感官性质上非常相似，但制造出的 Idiazabal 干酪感官特性则存在显著的差异。由亳状凝乳酶生产的 Idiazabal 干酪具有最高的气味和风 味强度值, 具有刺鼻性的气味, 浓重的凝乳酶气味和风味, 强烈的丁酸味和辛辣味。相反, 由商业凝乳酶生产的 Idiazabal 干酪具有柔和牛奶味和奶油味。

膏状小羊凝乳酶／卫生质量／感官性质／原产地命名保护／西班牙绵羊奶干酪／脂肪水解

Résumé - Qualité hygiénique, lipolyse et caractéristiques sensorielles de fromages espagnols d'Appellation d'Origine Protégée au lait de brebis élaborés à base de présure d'agneau en pâte. Des études ont été menées sur des préparations de présure à base de pâte de caillette d'agneau, afin de déterminer son adéquation à la fabrication des trois principaux fromages d'Appellation d'Origine Protégée en Espagne à base de lait cru de brebis (Manchego, Idiazabal et Zamorano), sous un aspect sanitaire et sensoriel. Ces fromages ont été fabriqués avec des préparations de caillette d'agneau (sous forme de pâte) ou avec des présures commerciales, aux forces de coagulation identiques (présure bovine en poudre pour le fromage Manchego et présure d'agneau liquide pour les fromages Zamorano et Idiazabal). Les acides gras libres et triglycérides partiels ont été analysés afin d'étudier les niveaux de lipolyse et les mettre en relation avec les caractéristiques sensorielles. Les comptages microbiologiques n'ont révélé aucune différence statistique significative en fonction des différentes présures, quelles que soient les espèces analysées. On peut conclure que la qualité hygiénique des fromages élaborés avec présure à base de pâte est comparable à ceux élaborés avec présure commerciale. Les fromages fabriqués à base de préparation de caillette d'agneau sous forme de pâte ont montré une lipolyse plus élevée que les fromages issus de présure commerciale. Les différences sensorielles entre les fromages issus des différents types de présure sont ressorties principalement dans le fromage Idiazabal, alors que les profils sensoriels pour les 2 types de présure sont apparus similaires pour les fromages Manchego et Zamorano. Les fromages Idiazabal fabriqués à partir de présure de caillette d'agneau ont montré des notations plus élevées en ce qui concerne l'intensité de l'odeur et de la flaveur, des odeurs pénétrantes, des odeurs de présure, des arômes butyriques et des caractères piquants. Par ailleurs, les fromages Idiazabal issus de présure commerciale révèlent des odeurs de lait et de beurre plus marquées que ceux élaborés avec présure à base de pâte.

présure d'agneau en pâte / fromage / lait de brebis / lipolyse / qualité hygiénique / propriétés sensorielles

\section{INTRODUCTION}

Commercial animal rennet is a mixture of enzymatic activities obtained from the 4 th stomach of ruminants. Chymosin is the main enzyme in the unweaned animal. Commercial rennets are the most widely used coagulants in today's cheese industry [58].

Lamb or kid rennet pastes are preferentially used in the manufacture of some ewe's or goat's milk cheeses in certain areas of the Mediterranean basin, such as Italy's Provolone, Pecorino Romano, Fiore Sardo or Pecorino Sardo [15, 16, 54], and Greece's artisanally-produced Kefalotyri and Feta cheeses [6, 7]. In Spain, artisanal rennet pastes are used by about $50 \%$ of the Idiazabal cheesemakers in the Basque Country (unpublished observations) and a handful of Majorero cheesemakers in the Canary Islands [29]. To the best of our knowledge, lamb or kid rennet pastes are commercially available only in Italy, but not in Spain or Greece, where cheesemakers prepare their own artisanal pastes according to different time-honoured recipes. 
Lamb rennet pastes, more frequently used than kid rennet pastes, have been the subject of recent research [1, 2, 23, 47]. Artisanal rennet pastes are prepared from abomasa of unweaned, milk-fed lambs, after drying and grinding them with various amounts of salt. In addition to chymosin and pepsin, these pastes contain variable amounts of lipolytic activities [1, 2, 23], including pregastric esterase, an enzyme secreted by glands at the base of the tongue and pushed down to the abomasa with the swallowed milk [28]. The activities of these enzymes vary from one rennet paste to another, depending on several factors such as the age and the state of the stomach when the animal was killed, and drying or salting procedures [23]. Lipolytic activities are not present in commercial liquid or powder rennets [28]. In order to activate the precursors of the coagulating activities during the manufacturing process, the $\mathrm{pH}$ is lowered to 2 [33], thus irreversibly inactivating lipolytic activities [23]. As a result, commercial liquid or powder rennets only have coagulating activities [33].

The use of lipase-containing lamb rennet pastes causes the accumulation of shortchain free fatty acids during cheese ripening $[1,2,48,57]$, which impart a characteristic "pungent" flavour to the cheese, as has been reported for Italy's Provolone and Romano cheeses [16], Feta cheese [6], Idiazabal cheese $[35,50,57]$ and other ewe's milk cheeses [44].

The use of artisanal rennet pastes has been progressively replaced, even in cheeses with Protected Denomination of Origin (PDO), by the use of commercial rennets. As a result, the cheeses lose some of their "traditional" sensory characteristics. This decline in the use of artisanal rennet pastes could be due to one or several of the following factors [23, 26]: (a) time-consuming and complex preparation procedures; (b) insufficient commercial supply; (c) lack of standardisation of their enzymatic activities, which results in a large variability in the sensory quality of the produced cheeses; and (d) their lower microbiological quality compared with commercial liquid or powder rennets. In the last few years, we have detected a renewed interest in the use of artisanal rennet pastes to recover "traditional" flavours in PDO cheeses, or to impart a different flavour to new products.

In the present work the use of lamb rennet paste in the manufacture of ewe's milk cheeses was investigated in two Spanish PDO cheeses which do not use it, Manchego and Zamorano, and in Idiazabal cheese, which accepts it as a frequently used coagulant, and was used as a reference. Together, these three PDO cheeses represent $91 \%$ of the ewe's milk cheese with PDO in Spain [36]. The objective was to compare, in commercial farmhouse fabrications (300-L vats), the behaviour of lamb rennet paste with a commercial liquid or powder rennet when the same amount of total coagulating strength was added to the same batch of milk. The hygienic quality, lipolysis and sensory properties of the cheeses were studied throughout ripening.

\section{MATERIALS AND METHODS}

\subsection{Rennets}

Lamb rennet paste was prepared in Cuajos Caporal, S.L. (Valladolid, Spain) from abomasa collected at various licensed abattoirs. At collecting time the stomachs were full of milk and of a light colour, indicating the absence of grass or other vegetable material. Immediately after collection the stomachs were placed in a cold $5 \% \mathrm{NaCl}$ solution and kept refrigerated for a maximum of 1 week. Lamb rennet paste was prepared by grinding the fresh tissue with $23 \%$ $\mathrm{NaCl}$, twice, in a commercial meat grinder. The paste had a coarse texture and it was further mixed in a commercial dough mixer until a smooth paste was obtained. This paste was kept at $5 \pm 1{ }^{\circ} \mathrm{C}$ in closed glass jars until used.

Commercial rennets were those used daily by each of the cheesemakers: commercial bovine rennet (Marschall powder, Rhône-Poulenc Texel, Dangé-Saint-Romain, France) for Manchego cheese; commercial lamb rennet (Caporal liquid, Cuajos Caporal, Valladolid, Spain) for Zamorano and Idiazabal cheeses. None of these rennets had lipase activity. 


\subsection{Cheese manufacture and cheese samples}

Cheeses were manufactured by two producers from each of the PDO: Idiazabal (Basque Country), Manchego (Castilla-La Mancha) and Zamorano (Castilla-León). All cheeses were made with raw milk from each cheesemaker's flock ("latxa", "manchega" and "churra" breeds for Idiazabal, Manchego and Zamorano cheeses, respectively) in commercial 300-L vats, following each cheesemaker's habitual procedures.

To prepare the lamb rennet extracts a given amount of rennet paste (between 20 and $25 \mathrm{~g} \cdot 100 \mathrm{~L}^{-1}$ of milk) was used. This amount of rennet paste was diluted in 150 $200 \mathrm{~mL}$ tap water at room temperature and stirred for about $1 \mathrm{~h}$. It was then filtered through cheesecloth and the filtrate was used to coagulate the milk.

On the same day and with the same milk, each cheesemaker manufactured under the same conditions two vats (one vat using the lamb rennet extract and the other vat using his or her daily commercial rennet). For each cheesemaker the amount of rennet paste to be used was adjusted so that the milk would coagulate in the same time as with the commercial rennet. In other words, the total coagulating strength added was the same, both for the commercial rennet and for the lamb rennet paste. Because coagulation times were slightly different for each cheesemaker, the amounts of lamb rennet paste were also slightly different: $20 \mathrm{~g} \cdot 100 \mathrm{~L}^{-1}$ for Manchego cheese and $25 \mathrm{~g} \cdot 100 \mathrm{~L}^{-1}$ for Idiazabal and Zamorano cheeses. A manufacturing replicate was done within 1 week. Each cheesemaker used his (or her) customary manufacturing and ripening procedures. From each fabrication two whole cheeses were taken for physico-chemical and microbiological analysis on the following days of ripening: 2, 60, 90 and 180 d for Idiazabal cheeses; 2, 60, 120 and 180 d for Manchego cheeses; and 2, 60, 180 and $240 \mathrm{~d}$ for Zamorano cheeses. All samples were maintained at 3$4{ }^{\circ} \mathrm{C}$ during transport to the laboratory and microbiological analyses were performed within $24 \mathrm{~h}$. Each cheese was cut into 8 wedges of equal weight, wrapped in clear plastic film and aluminium foil and kept at $-30{ }^{\circ} \mathrm{C}$ until analysed. A third cheese from each vat was taken at different days for sensory evaluation, according to the usual commercialisation times for each PDO: 90 and $180 \mathrm{~d}$ of ripening for Idiazabal cheese; 120 and $180 \mathrm{~d}$ of ripening for Manchego cheese; and 180 and $240 \mathrm{~d}$ of ripening for Zamorano cheese. Cheeses for sensory evaluation were kept at $5 \pm 1{ }^{\circ} \mathrm{C}$ for a maximum of 1 week.

\subsection{Microbiological analysis}

Microbiological analyses were carried out on samples from milk, lamb rennet paste, lamb rennet extracts prior to addition to the milk and cheeses. Duplicate analyses were performed. Microbiological analyses in samples of rennet pastes and rennet extracts were carried out as required by the Spanish legislation [19]. The following microorganisms were determined: aerobic mesophilic bacteria, Enterobacteriaceae, Escherichia coli, enterotoxigenic staphylococci, sulphite-reducing clostridia, moulds and yeasts and Salmonella spp. In addition to these microorganisms, the presence of Listeria monocytogenes was studied in rennet extracts, whereas in milk and cheese samples coliforms, Listeria monocytogenes, and the above-mentioned microorganisms, except Enterobacteriaceae, were determined [31]. Samples (10 g or $10 \mathrm{~mL}$ ) were homogenised in $90 \mathrm{~mL}$ of sterile $2 \%$ $(\mathrm{w} / \mathrm{v})$ sodium citrate solution (Merck, Darmstadt, Germany) in a Colworth Stomacher 400 (A.J. Seward Ltd., London, UK). Decimal dilutions of the homogenate were prepared by mixing $10 \mathrm{~mL}$ with $90 \mathrm{~mL}$ of $0.1 \%$ (w/v) sterile peptone water solution (Oxoid, Unipath Ltd., Basingstoke, UK) as described in IDF [40].

Specific media were used to enumerate the different microbial groups: aerobic mesophilic bacteria on standard Plate Count Agar (PCA, Oxoid) after incubation at $30{ }^{\circ} \mathrm{C}$ for $72 \mathrm{~h}$; Enterobacteriaceae on Violet Red Bile Dextrose Agar (VRBG, Oxoid) after incubation at $37^{\circ} \mathrm{C}$ for $24 \mathrm{~h}$, and coliforms on Violet Red Bile Agar (VRBA, Oxoid) after incubation at $30{ }^{\circ} \mathrm{C}$ for 24 h [52]; Escherichia coli on Selective 
Chromogenic Medium Coli ID (BioMérieux, Marcy-L'Étoile, France) incubated at $44{ }^{\circ} \mathrm{C}$ for $24 \mathrm{~h}$ [5]; enterotoxigenic staphylococci on Baird-Parker RPF-Agar (BioMérieux) incubated at $37{ }^{\circ} \mathrm{C}$ for $48 \mathrm{~h}$ [4]; sulphite-reducing clostridia on Sulphite Polymyxin Sulphadiazine Agar (SPS, Merck) incubated at $46^{\circ} \mathrm{C}$ for $48 \mathrm{~h}$; and moulds and yeasts on Oxytetracycline Glucose Yeast Extract Agar (OGYE, Oxoid) incubated at $20^{\circ} \mathrm{C}$ for $5 \mathrm{~d}$ [52]. One $\mathrm{mL}$ of each dilution was pour-plated in standard PCA, VRBG, VRBA, Coli ID, SPS and OGYE agar, in duplicate, and mixed before solidification. Plates of VRBG and VRBA were covered with a layer of the same medium before incubation. In Baird-Parker RPF-agar, $0.1 \mathrm{~mL}$ of each dilution was spread-plated in duplicate. For the investigation of Salmonella spp. $25 \mathrm{~g}$ or $25 \mathrm{~mL}$ of sample were homogenised in $225 \mathrm{~mL}$ of $1 \%$ $(\mathrm{w} / \mathrm{v})$ sterile peptone water solution (BioMérieux) using a Colworth Stomacher 400 and incubated at $37^{\circ} \mathrm{C}$ for $20 \mathrm{~h}$. An aliquot of homogenate $(0.1 \mathrm{~mL})$ was incubated in $10 \mathrm{~mL}$ of Rappaport Vassiliadis medium (Oxoid) at $42^{\circ} \mathrm{C}$ for $48 \mathrm{~h}$ and a second aliquot of $1 \mathrm{~mL}$ was incubated in $10 \mathrm{~mL}$ of Mueller Kauffman Tetrathionate Broth Medium (Oxoid) at $37^{\circ} \mathrm{C}$ for $48 \mathrm{~h}$. Xilose Lysine Decarboxylase agar (XLD, BioMérieux) and Chromogenic SMID (BioMérieux) were surface-plated with each of the cultures obtained from the previous media and incubated at $37^{\circ} \mathrm{C}$ for $24 \mathrm{~h}$. Representative numbers of suspicious colonies were verified by standard biochemical and serological procedures [52]. Listeria monocytogenes was determined according to ISO [42].

\subsection{Enzyme activities}

\subsubsection{Total coagulating strength}

Lamb rennet pastes were homogenised $\left(0.1 \mathrm{~g} \cdot \mathrm{L}^{-1}\right.$ deionised water) on ice for $10 \mathrm{~min}$ in a Potter-Elvejhem-type homogeniser (Braun Melsungen, Germany) and solids were removed by filtering through a fine plastic mesh. The coagulating activity was determined in duplicate as described in IDF [39] and by Bustamante et al. [23]. Chymosin and pepsin were separated by ionexchange chromatography on Fractogel EMD
DEAE 650 (Merck, Darmstadt, Germany), and quantified as described in IDF [39], with the modifications described by Bustamante et al. [23]. The concentration of chymosin and pepsin was expressed as a percentage of the total coagulating activity.

\subsubsection{Lipase activity}

The lipase activity assay was adapted from the $\mathrm{pH}$-stat method described by Barton et al. [14] with the modifications described by Svensson et al. [56], using tributyrin as substrate. Lamb rennet pastes were homogenised $\left(0.1 \mathrm{~g} \cdot \mathrm{mL}^{-1}\right)$ on ice for about $10 \mathrm{~min}$ and filtered through a fine plastic mesh. Extracts were kept at $4{ }^{\circ} \mathrm{C}$ and activity was determined in triplicate within $1 \mathrm{~h}$. One unit of lipase activity (LU) is defined as the amount of enzyme necessary to produce $1 \mu \mathrm{mol}$ of butyric acid per minute, considering that $1 \mu \mathrm{mol}$ of $\mathrm{NaOH}$ is equivalent to $1 \mu \mathrm{mol}$ of butyric acid under these reaction conditions.

\subsection{Physico-chemical analysis}

The physico-chemical analysis performed in duplicate was: dry matter extract [38]; protein content [37]; fat content [41]; sodium chloride content, as described by Barrios [11]; pH, as described by Berdagué and Grappin [17]; and water activity using a Novasina water activity meter (model Sprint-TH500; Novatron, Horsham, UK).

\subsection{Free fatty acids analysis}

Free fatty acids (FFA) were extracted and analysed underivatised by gas chromatography with a flame ionisation detector, as described by Chavarri et al. [27]. Quantification was done with $n$-pentanoic, $n$-nonanoic and $n$-heptadecanoic acids (Sigma-Aldrich, Alcobendas, Spain) as internal standards added to cheese samples at the time of extraction $(100 \mu \mathrm{L}$ of $1 \mathrm{mg} \cdot \mathrm{mL}^{-1}$ solution of each fatty acid in $n$-heptane). Extraction and analyses were done in duplicate.

\subsection{Partial glycerides and free cholesterol analysis}

Partial glycerides and free cholesterol were extracted and analysed by high-performance 
liquid chromatography with a light-scattering detector, as described by Barron et al. [12]. Quantification was done with hexadecanediol (Sigma-Aldrich) as internal standard added to cheese samples at the time of extraction ( $2 \mathrm{mg}$ to $3 \mathrm{~g}$ of ground cheese). The results were expressed as mg $100 \mathrm{~g}^{-1}$ for $(1,2+2,3)$-diglycerides (DG), 1,3-DG, $(1+3)$-monoglycerides (MG), 2-MG and free cholesterol. Extraction and analyses were done in duplicate.

\subsection{Sensory evaluation}

Samples were assessed by a team of eight panellists who had previously been selected and trained in the sensory characterisation of ewe's milk cheeses [9]. Four cheeses were evaluated in each session, each one from a different fabrication ( 2 cheeses of each of the 2 types of rennet). Latin squares design was used for sample presentation to minimise the effect of serving order, as suggested by Muir and Hunter [49]. The following sensory attributes were assessed on a seven-point scale: seven odour attributes (overall odour intensity, sharp, milky, brine, buttery, toasty and rennet); ten flavour attributes (overall flavour intensity, butyric acid, nutty, buttery, sweet, acid, bitter, salty, pungent and rennet); and nine texture attributes (surface roughness, surface moisture, elasticity, firmness, friability, adhesiveness, microstructure, solubility and humidity in the mouth). The scale development, attribute selection, and standard references used in this study were described previously by Bárcenas et al. [8].

Cheese samples were evaluated as described by Bárcenas et al. [10]. Cheese samples were presented as $1.5 \mathrm{~cm}$ thick $\times$ $1.5 \mathrm{~cm}$ wide $\times 5-8 \mathrm{~cm}$ long portions, with the rinds cut away. Two portions per sample were served, one to evaluate texture and the other to evaluate odour and flavour [45]. The serving temperature was $16-18{ }^{\circ} \mathrm{C}$ [18]. Low mineralisation water and solid food (apple or biscuit without salt) were used to remove any aftertaste between samples. Sensory assessment was performed in standard individual tasting booths [3].

\subsection{Statistical analysis}

SPSS software, version 12.0 (SPSS, Chicago, IL, USA) was used for the statistical analysis. Two-way analysis of covariance (ANCOVA) was done to establish the presence or absence of significant differences $(P \leq 0.05)$ in microbiological, compositional and sensory parameters of the cheeses according to the factors "rennet type" and "PDO cheese", using the "ripening time" as covariate. When the interaction term was significant, one-way analysis of variance (ANOVA) was used to determine the presence or absence of significant differences $(P \leq 0.05)$ in microbiological, compositional and sensory parameters among the PDO cheeses made either with lamb rennet paste or commercial rennet at the same ripening time. Student's $t$ test was used to evaluate the significance of the differences $(P \leq 0.05)$ in microbiological, compositional and sensory parameters between cheeses of the same PDO variety made with lamb rennet paste or commercial rennet at the same ripening time.

\section{RESULTS AND DISCUSSION}

\subsection{Microbiological and enzymatic characteristics of the lamb rennet paste}

The lamb rennet paste had higher counts than allowed by the current Spanish legislation for commercial rennets [19] for sulphite-reducing clostridia, moulds and yeasts, although no Enterobacteriaceae, Escherichia coli, Staphilococcus aureus or Salmonella were detected (Tab. I). At present, there is no European legislation regulating the microbiological counts for commercial rennets.

Total aerobic mesophilic bacterial counts found in kid and lamb rennet pastes range from $10^{3}$ to $10^{6}[25,26,47]$. S. aureus in these studies was not detected or counts were very low $\left(<100 \mathrm{cfu} \cdot \mathrm{g}^{-1}\right)$. Regarding the sulphite-reducing clostridia, Calandrelli et al. [25] reported $<10 \mathrm{cfu} \cdot \mathrm{g}^{-1}$ for kid rennet pastes and Moatsou et al. [47] reported $70 \mathrm{cfu} \cdot \mathrm{g}^{-1}$ for anaerobic spore-forming 
Table I. Mean and standard deviation of microbiological counts $\left(\log \mathrm{cfu} \cdot \mathrm{g}^{-1}\right)$ and enzyme activities in the lamb rennet paste used in the manufacture of PDO cheeses.

\begin{tabular}{|c|c|c|}
\hline & Counts & $\mathrm{BOE}[19]^{\mathrm{a}}$ \\
\hline Total aerobic mesophiles & $4.52 \pm 0.06$ & 5 \\
\hline Enterobacteriaceae & $\mathrm{ND}^{\mathrm{b}}$ & 1 \\
\hline Escherichia coli & ND & $1 \log \mathrm{cfu} \cdot \mathrm{g}^{-1}$ \\
\hline Sulphite-reducing clostridia & $3.06 \pm 0.04$ & $1 \log \mathrm{cfu} \cdot \mathrm{g}^{-1}$ \\
\hline Staphilococcus aureus & ND & Absence in $1 \mathrm{~g}$ \\
\hline Moulds and yeasts & $2.56 \pm 0.43$ & $1 \log \mathrm{cfu} \cdot \mathrm{g}^{-1}$ \\
\hline \multirow[t]{2}{*}{ Salmonella spp (presence / absence) } & ND & Absence in $25 \mathrm{~g}$ \\
\hline & Activity values & \\
\hline Coagulating strength $\left(R U \cdot g^{-1}\right)$ & $90 \pm 2$ & \\
\hline Chymosin (\% of total coagulating strength) & $80 \%$ & \\
\hline Pepsin (\% of total coagulating strength) & $20 \%$ & \\
\hline Lipase activity $\left(\mathrm{LU} \cdot \mathrm{g}^{-1}\right)$ & $2.0 \pm 0.2$ & \\
\hline
\end{tabular}

a Maximum limits established by the Spanish legislation (Boletín Oficial del Estado) for commercial rennets.

b ND: not detected.

microorganisms in lamb and kid rennet pastes. The data provided by Callandrelli et al. [25] for moulds and yeasts range from $<100$ to $10^{4} \mathrm{cfu} \cdot \mathrm{g}^{-1}$, whereas Moatsou et al. [47] reported counts of $30 \mathrm{cfu} \cdot \mathrm{g}^{-1}$.

The total coagulating strength and the lipase activity (Tab. I) were about half the values reported by Virto et al. [57], most likely due to the fact that in the present work the rennet paste was prepared from fresh tissue, instead of using dried abomasa. From a practical point of view, the value of the lipase activity $\left(2.0 \pm 0.2 \mathrm{LU} \cdot \mathrm{g}^{-1}\right)$ was considered to be more convenient than the values reported by Virto et al. [57] or by Bustamante et al. [23] to minimise the risk of overdose, which could yield very strongly-flavoured cheeses [35].

\subsection{Microbiological characteristics of ewe's milk and rennet paste extract}

The microbiological counts of the ewe's milks used in the present study appear in Table II. Differences observed among the milks could be explained by differences in the milk production systems used by each cheesemaker (milking routine, hygiene and refrigeration time).
On each manufacturing day, each cheesemaker prepared her (or his) own aqueous rennet extract from the same lamb rennet paste supplied. The differences detected in the microbiological counts for the rennet extracts (Tab. II) among cheesemakers are probably due to differences in handling and/or to different environmental contamination levels, as has been observed in a previous study (unpublished data). Also, Irigoyen et al. [43] found large differences in counts in rennet extracts for total aerobic mesophiles, Enterobacteriaceae, moulds and yeast.

\subsection{Physico-chemical characteristics of cheeses}

The use of lamb rennet paste did not significantly influence $(P>0.05)$ the values of the general physico-chemical parameters studied. On each ripening day and for each $\mathrm{PDO}$, no statistically significant differences were found for the values of the physico-chemical parameters studied between cheeses made with lamb rennet paste or with commercial rennet. The mean values for dry matter increased from $56.2 \% \pm 1.1$ (on ripening $\mathrm{d} 1$ ) to $69.9 \% \pm 1.8$ (on ripening $\mathrm{d} 180$ ) for Idiazabal cheeses, from $58.9 \% \pm 0.7$ 
Table II. Mean and standard deviation (duplicate trials done in each of two factories) of microbiological counts (log $\left.\mathrm{cfu} \cdot \mathrm{mL}^{-1}\right)$ in ewe's raw milks and lamb rennet extracts used in the manufacture of PDO cheeses.

\begin{tabular}{|c|c|c|c|c|c|c|}
\hline & \multicolumn{3}{|c|}{ Milk } & \multicolumn{3}{|c|}{ Rennet extract } \\
\hline & Idiazabal & Manchego & Zamorano & Idiazabal & Manchego & Zamorano \\
\hline Aerobic mesophiles & $4.7 \pm 0.5$ & $7.9 \pm 0.7$ & $6.4 \pm 0.8$ & $3.8 \pm 0.2$ & $5.7 \pm 0.0$ & $3.7 \pm 0.3$ \\
\hline $\begin{array}{l}\text { Coliforms (milk) } \\
\text { Enterobacteriaceae (rennet) }\end{array}$ & $2.5 \pm 0.7$ & $3.6 \pm 0.3$ & $4.9 \pm 0.9$ & $0.6 \pm 1.0$ & $\mathrm{ND}^{\mathrm{a}}$ & $1.2 \pm 1.0$ \\
\hline Escherichia coli & $1.1 \pm 1.2$ & $1.8 \pm 0.8$ & $1.3 \pm 1.1$ & ND & ND & ND \\
\hline Sulphite-reducing clostridia & $0.5 \pm 0.3$ & $0.9 \pm 1.3$ & ND & $2.1 \pm 0.2$ & $2.4 \pm 0.1$ & $2.2 \pm 0.4$ \\
\hline Enterotoxigenic staphylococci & $0.4 \pm 0.7$ & $3.0 \pm 1.4$ & $3.2 \pm 1.0$ & ND & $0.4 \pm 0.5$ & ND \\
\hline Moulds and yeasts & $2.6 \pm 0.4$ & $5.9 \pm 0.2$ & $3.1 \pm 0.4$ & $2.4 \pm 0.4$ & $3.2 \pm 0.6$ & $2.3 \pm 0.6$ \\
\hline Salmonella spp & ND & ND & ND & ND & ND & ND \\
\hline Listeria monocytogenes & ND & ND & ND & ND & ND & ND \\
\hline
\end{tabular}

a ND: not detected.

(on ripening $\mathrm{d} 1$ ) to $67.5 \% \pm 0.3$ (on ripening d180) for Manchego cheeses and from $54.5 \% \pm 0.9$ (on ripening $\mathrm{d} 1$ ) to $71.6 \% \pm 2.5$ (on ripening $\mathrm{d} 240$ ) for Zamorano cheeses. The mean values for protein content in dry matter decreased from $38.7 \% \pm 2.4$ (on ripening $\mathrm{d} 1$ ) to $36.1 \% \pm 1.6$ (on ripening $\mathrm{d} 180$ ) for Idiazabal cheeses, from $37.3 \% \pm 0.8$ (on ripening $\mathrm{d} 1$ ) to $35.6 \% \pm 1.3$ (on ripening d180) for Manchego cheeses and from $35.7 \% \pm 0.6$ (on ripening d 1 ) to $32.8 \% \pm 0.2$ (on ripening d240) for Zamorano cheeses. The tendency for fat content in dry matter for the cheeses was not the same for all the batches. In some cases it increased a bit and in other cases it decreased a bit, where the minimum value obtained was $49.7 \% \pm 1.0$ and the maximum was $57.9 \% \pm 2.0$. The content of $\mathrm{NaCl}$ in total matter increased from $1.4 \% \pm 0.3$ (on ripening $\mathrm{d} 1$ ) to $2.5 \% \pm$ 0.1 (on ripening d180) for Idiazabal cheese, from $1.4 \% \pm 0.3$ (on ripening $\mathrm{d} 1$ ) to $2.5 \% \pm$ 0.1 (on ripening d180) for Manchego cheese and from $1.4 \% \pm 0.3$ (on ripening d1) to $2.5 \% \pm 0.1$ (on ripening d180) for Zamorano cheese.

As with the fat content, there is not a clear tendency for the evolution of $\mathrm{pH}$; for some batches it increased a bit and for other batches it decreased a bit. The extreme values were $5.5 \pm 0.1$ and $5.3 \pm 0.1$ for Idiaza- bal cheeses, $5.4 \pm 0.0$ and $5.8 \pm 0.0$ for Manchego cheeses and $5.4 \pm 0.1$ and $5.6 \pm$ 0.0 for Zamorano cheeses. Water activity decreased for all the cheeses studied, from $0.988 \pm 0.002$ (on ripening $\mathrm{d} 1$ ) to $0.932 \pm$ 0.004 (on ripening $\mathrm{d} 180$ ) for Idiazabal cheese, from $0.993 \pm 0.003$ (on ripening d1) to $0.934 \pm 0.006$ (on ripening $\mathrm{d} 180$ ) for Manchego cheese and from $0.991 \pm 0.002$ (on ripening $\mathrm{d} 1$ ) to $0.913 \pm 0.018$ (on ripening d240) for Zamorano cheese.

In agreement with our results, other authors such as Virto et al. [57] in Idiazabal cheese and Moatsou et al. [47] in Feta cheese did not observe statistically significant differences in physico-chemical parameters between cheeses made with artisanally-produced rennets and cheeses made with commercial calf rennet. The three PDO cheeses fulfilled the physicochemical criteria at the ripening time for commercialisation established in their respective regulations: $\mathrm{BOE}$ [20] for Idiazabal cheese, BOE [21] for Zamorano cheese and BOE [22] for Manchego cheese.

\subsection{Microbiological characteristics of the cheeses}

The microbiological counts shown in Table III in Idiazabal and Zamorano 


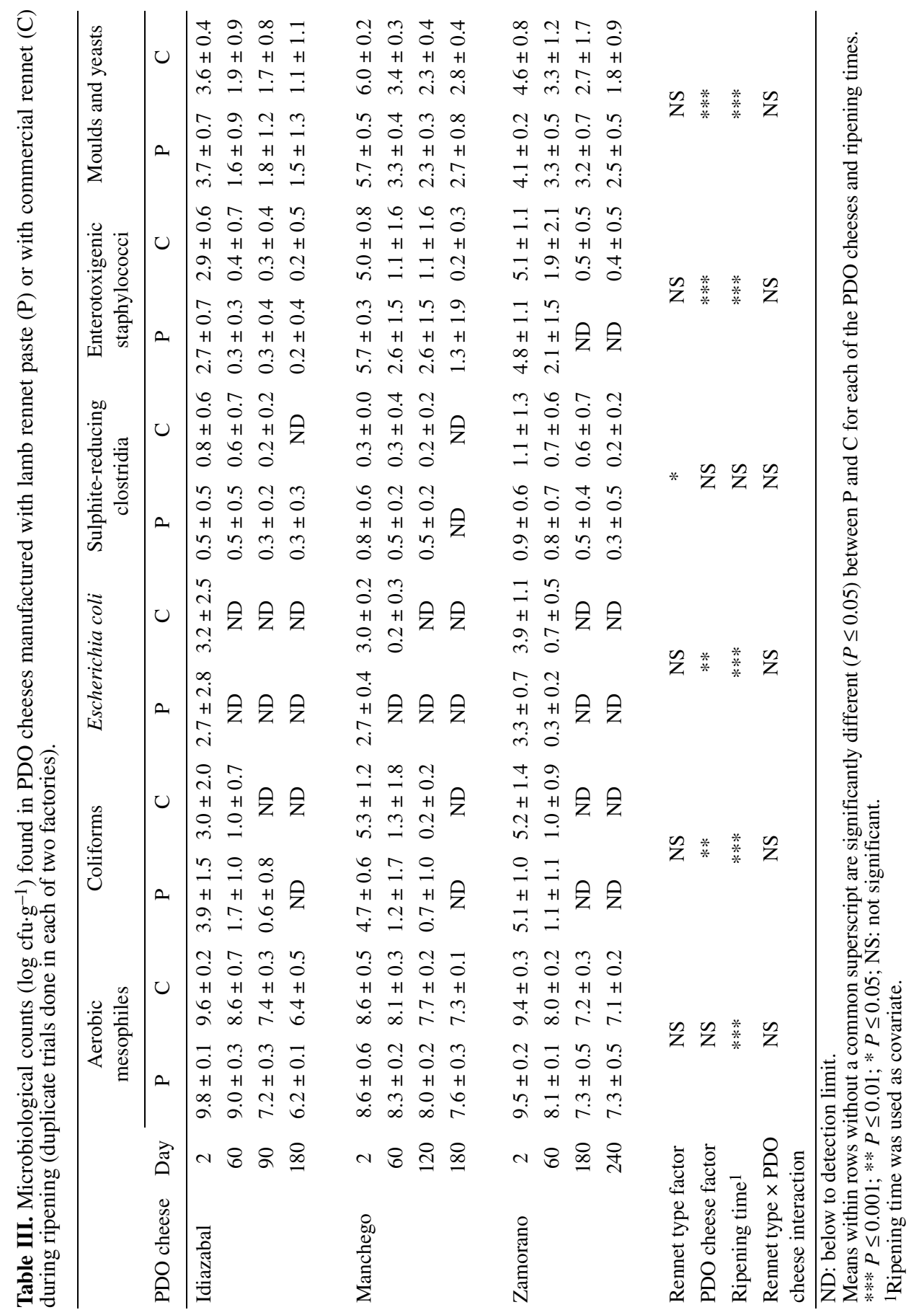


Table IV. Significance level $(P)$ and effect size of the two-way ANCOVA for the factors "rennet type" and "PDO cheese" using ripening time as covariate on the free fatty acid (FFA), diglyceride (DG), monoglyceride (MG) and free cholesterol contents of the cheeses.

\begin{tabular}{lccccccc}
\hline & \multicolumn{2}{c}{ PDO cheese } & \multicolumn{2}{c}{ Rennet type } & $\begin{array}{c}\text { PDO cheese } \times \text { Rennet } \\
\text { type interaction }\end{array}$ & $\begin{array}{c}\text { Ripening } \\
\text { time }\end{array}$ \\
\cline { 2 - 7 } & $P$ & Effect size & $P$ & Effect size & $P$ & Effect size & $P$ \\
\hline Short-chain FFA & $* * *$ & 0.569 & $* * *$ & 0.343 & $* * *$ & 0.765 & $* * *$ \\
Medium-chain FFA & $* * *$ & 0.543 & $* *$ & 0.121 & $* * *$ & 0.350 & $* * *$ \\
Long-chain FFA & $* * *$ & 0.325 & $*$ & 0.074 & $*$ & 0.112 & $* * *$ \\
Total FFA & $* * *$ & 0.538 & $* * *$ & 0.286 & $* * *$ & 0.651 & $* * *$ \\
1,3-DG & $* * *$ & 0.371 & NS & 0.001 & NS & 0.000 & $* * *$ \\
$(1,2+2,3)-D G$ & $* * *$ & 0.489 & NS & 0.002 & NS & 0.003 & $* * *$ \\
$(1+3)-M G$ & $* * *$ & 0.917 & $* * *$ & 0.283 & $* * *$ & 0.385 & $* * *$ \\
2-MG & $* * *$ & 0.500 & NS & 0.000 & NS & 0.000 & $* * *$ \\
Free cholesterol & $* * *$ & 0.489 & NS & 0.002 & NS & 0.004 & $* * *$ \\
\hline
\end{tabular}

*** $P \leq 0.001 ; * * P \leq 0.01$; $P \leq 0.05$; NS: not significant.

cheeses made with lamb rennet paste were not significantly different $(P>0.05)$ from counts in cheeses made with commercial rennet on all days of ripening studied. In Manchego cheeses only the levels of sulphite-reducing clostridia in cheeses made with lamb rennet paste were significantly higher $(P \leq 0.05)$ than those found in cheeses made with commercial rennet until $120 \mathrm{~d}$ of ripening, disappearing by $180 \mathrm{~d}$ of ripening. No Salmonella or Listeria monocytogenes were found at any time for any of the PDO cheeses studied. As ripening progressed, the counts of these microbiological groups decreased in the three PDO cheeses, in accordance with the observations of PérezElortondo et al. [53] for Idiazabal cheese.

At commercialisation time, all cheeses fulfilled the microbiological criteria established in the European legislation for raw milk cheeses [31], regardless of the rennet used. Moatsou et al. [47] reported that the microbiological quality of artisanallyprepared lamb and kid rennet significantly affected the microbiological quality of 3day-old Feta cheeses, but this influence disappeared in the mature 60-day-old cheeses. Callandrelli et al. [25] reported similar results in Semicotto cheese manufactured with kid rennet. Thus, it can be concluded that lamb rennet pastes, having higher microbiological counts than commercial rennets, do not compromise the microbiological quality of the cheeses made with them at commercialisation time.

\subsection{Lipolysis}

Because the lamb rennet paste used contained lipase activity, the concentration of free fatty acids (FFA) and of partial glycerides was measured throughout ripening.

The significance level and effect size for the factors "rennet type" and "PDO cheese" in the FFA and glyceride contents are shown in Table IV. As expected, FFA, glyceride and free cholesterol contents were significantly different $(P \leq 0.001)$ among the PDO cheeses. The rennet type and the interaction term between PDO cheese and rennet type had a significant effect $(P \leq 0.05)$ on the short, medium, large and total FFA and $(1+3)$-MG. Therefore, the addition of lamb rennet paste showed a different effect on the lipolysis of each PDO cheese. In this sense, because the concentration of shortchain FFA has been related to sensory attributes desirable in different ewe's cheeses $[12,13]$, it could be expected that the use of lamb rennet paste might obtain different sensory results, depending on the PDO cheese (Idiazabal, Manchego or Zamorano). 


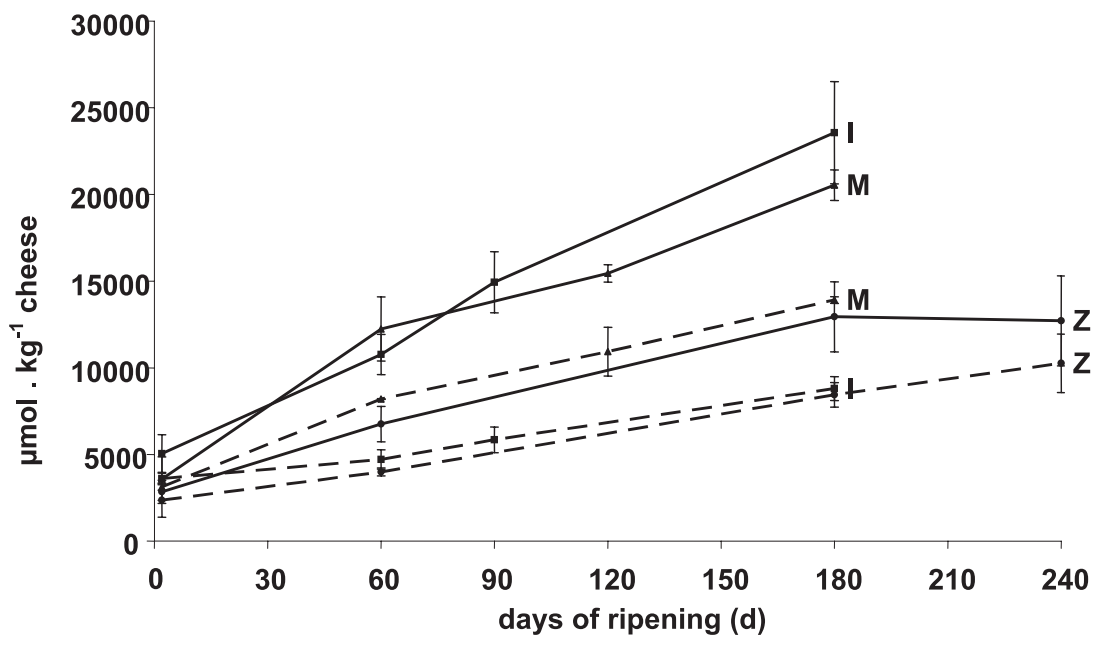

Figure 1. Total free fatty acid content throughout ripening.

I: Idiazabal cheese; M: Manchego cheese; Z: Zamorano cheese; continuous line: cheeses made with lamb rennet paste; discontinuous line: cheeses made with commercial rennet.

As expected, levels of FFA in cheeses manufactured with lamb rennet paste were significantly higher $(P \leq 0.05)$ than those in cheeses of the same PDO manufactured with commercial rennet (Fig. 1). However, the total amount of FFA in each type of cheese was different, although the amounts of lipase activity added were comparable (40 LU.100 $\mathrm{L}^{-1}$ of milk for Manchego cheese and $50 \mathrm{LU} \cdot 100 \mathrm{~L}^{-1}$ of milk for Idiazabal and Zamorano cheeses). Idiazabal cheese had the highest levels of FFA after 90 and $180 \mathrm{~d}$ of ripening. The amount accumulated after $90 \mathrm{~d}$ of ripening was comparable with the results reported by Virto et al. [57] for 90-day-old Idiazabal cheeses made with a similar amount of lipase by different cheesemakers. The FFA concentration in Manchego cheeses after $180 \mathrm{~d}$ was significantly lower $(P \leq 0.05)$ than that in 180day-old Idiazabal cheeses, perhaps due to the slightly lower amount of lipase used in these cheeses. The low FFA concentration observed in Zamorano cheeses (about half the concentration found in Idiazabal cheeses) was totally unexpected, considering that the same amount of lipase had been used, and difficult to explain. No significant difference $(P>0.05)$ was observed in FFA content between Idiazabal and Zamorano cheeses made with commercial bovine rennet, but significantly higher $(P \leq 0.05)$ content was found in Manchego cheese during ripening (Fig. 1). Lipolysis in cheeses manufactured with no lipase added is considered to be due to the lipoprotein lipase present in raw milk and to the lipolytic activity of the microorganisms present during ripening $[28,30]$, which could account for the observed differences among the cheeses.

The FFA composition of all cheeses manufactured with lamb rennet paste was significantly different $(P \leq 0.05)$ from that of all cheeses manufactured with commercial rennet (Fig. 2). Short-chain (C4-C10) FFA were the most abundant FFA in the 3 types of cheeses manufactured with lamb rennet paste, with percentages varying between 55\% (Zamorano) and 68\% (Idiazabal) of the total. However, the difference between the percentage of short-chain FFA and long-chain ( $\geq \mathrm{C} 16)$ FFA was only $20 \%$ points in Zamorano cheeses (Fig. 2), but $45 \%$ points in Idiazabal cheeses. These results suggest that, in spite of the similar amounts of lipase activity added with the rennet paste to the three different cheeses, 

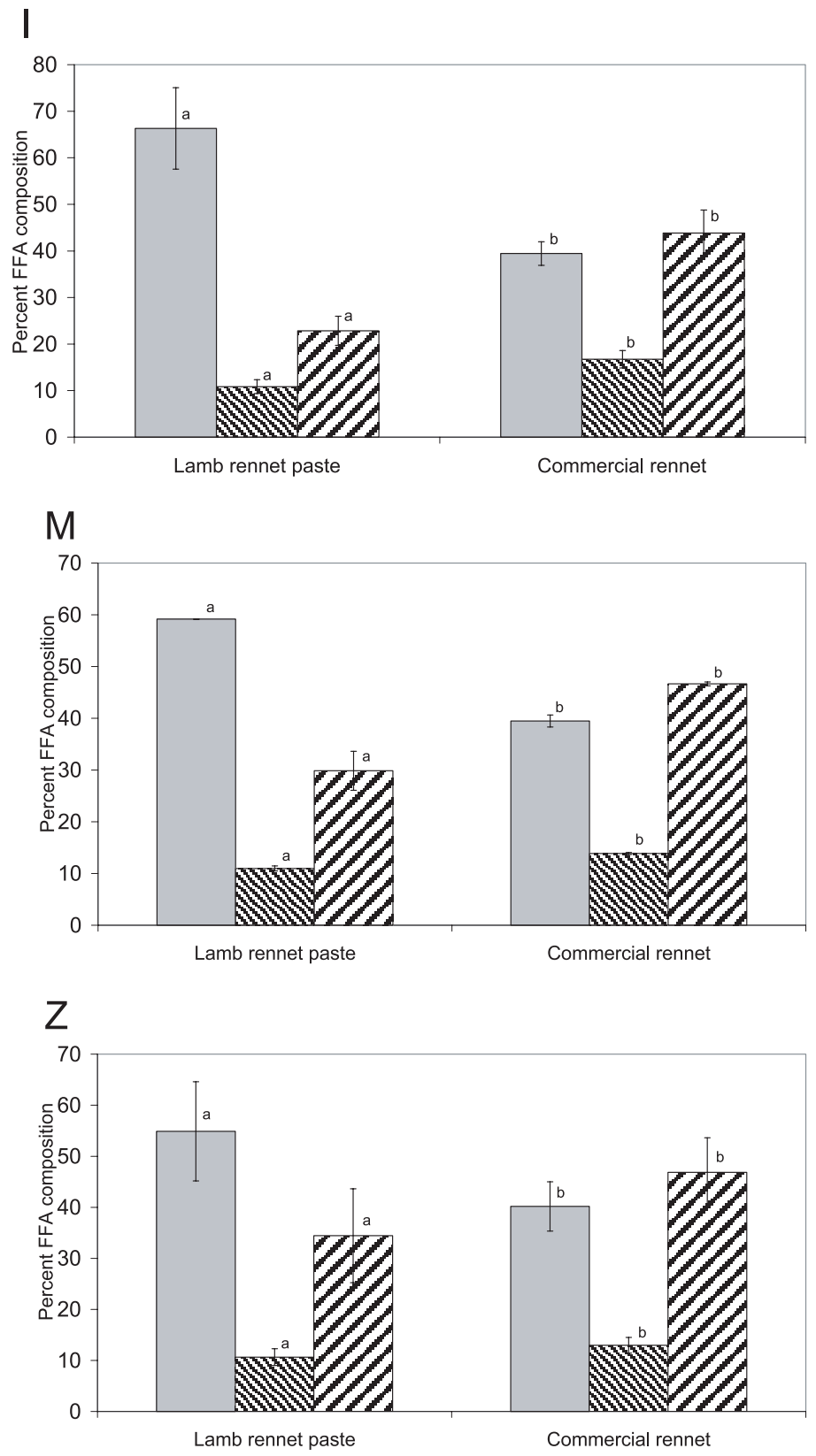

Figure 2. Free fatty acid (FFA) composition of Idiazabal (I), Manchego (M) and Zamorano (Z) cheeses after 180 days of ripening. Means within bars without a common superscript are significantly $(P \leq 0.05)$ different between cheeses made with lamb rennet paste and with commercial rennet for each of the cheese varieties.

$\square$ Short-chain FFA; Medium-chain FFA; $\square$ Long-chain FFA. 
the balance of lipolytic activities present in them during ripening must have been quite different. The results for Idiazabal cheese agree with those reported by Virto et al. [57] and Hernández et al. [35] for cheeses manufactured by different cheesemakers with amounts of lipase activity comparable with those used in the present study, demonstrating that at least in Idiazabal cheese, similar amounts of added lipase activity result in similar amounts of total FFA. In contrast, the FFA composition of the three types of cheeses manufactured with commercial rennet was essentially identical (Fig. 2).

Although they are not frequently analysed, partial glycerides are products of the hydrolysis of triacylglycerols (TAG) by lipases, together with FFA. Also, the hydrolysis of cholesteryl esters is catalysed by lipases releasing free cholesterol during cheese ripening [34]. The concentration of various partial glycerides and free cholesterol for the three PDO cheeses made with lamb rennet paste or with commercial rennet after $180 \mathrm{~d}$ of ripening is presented in Table V. $(1,2+2,3)$-DG were the major partial glycerides present in all PDO cheeses, occurring in slightly higher amounts than (1,3)-DG, particularly for the cheeses made with lamb rennet paste. Unexpectedly, monoglycerides occurred in Idiazabal cheeses made with lamb rennet paste and with commercial rennet, but were completely absent in all Zamorano cheeses and in Manchego cheeses manufactured with lamb rennet paste. Also, Zamorano cheeses made with lamb rennet paste had a significantly higher $(P \leq 0.05)$ content of $(1,2+$ 2,3)-DG than Zamorano cheeses made with commercial rennet (Tab. V).

The differences related to the effect of the use of lamb rennet paste among the three PDO cheeses found in the present work could be due to any, or a combination of, at least the following two factors: (a) a different balance of lipolytic activities (microbial and those added with the rennet paste) with different substrate specificities present during cheese ripening; and (b) different total amounts of the individual TAG molecular species, particularly those containing shortchain fatty acids. The lipase present in lamb rennet pastes is highly specific for short- chain fatty acids sterified in the $s n-3$ position of the TAG [51], preferentially liberating them from milk fat TAG [46]. Stadhouders and Veringa [55] showed that certain microbial lipases are specific for MG. Recently, Fontecha et al. [32] have analysed the TAG composition of milk fat from five different breeds of sheep in the central region of Spain, including "churra" and "manchega", used in Zamorano and Manchego PDO cheeses, respectively. Their results indicated that the individual TAG content (expressed in mol \%) was very similar for the different breeds of sheep. However, they did not control the possible differences in TAG composition due to diet and stage of lactation between herds, and they did not provide data regarding total amounts of the different TAG molecular species. Different total amounts of short-chain fatty acid-containing TAG would explain, in part, the differences in the total concentration of FFA found among the three PDO cheeses reported in this work, in spite of using comparable amounts of added lipolytic activity. In addition to these possible explanations, it should not be forgotten that the total amount of a given metabolite accumulated on a certain ripening day is the result of both synthetic and degradative processes, neither of which have been independently studied to the best of our knowledge.

\subsection{Sensory profiles}

The sensory profiles of all cheeses are shown in Figures 3 and 4. Statistically significant differences $(P \leq 0.05)$ between cheeses made with lamb rennet paste or with commercial rennet were found, primarily for Idiazabal cheese. Odour intensity, sharp and rennet odour (Fig. 3); and flavour intensity, butyric acid and rennet and pungent flavour (Fig. 4) received higher scores in Idiazabal cheeses made with lamb rennet paste than in those cheeses made with commercial rennet. These attributes were positively correlated with the "lamb rennet paste factor" in a principal component analysis carried out by Bustamante et al. [24]. Cheeses made with commercial rennet had higher scores for milk odour and buttery 


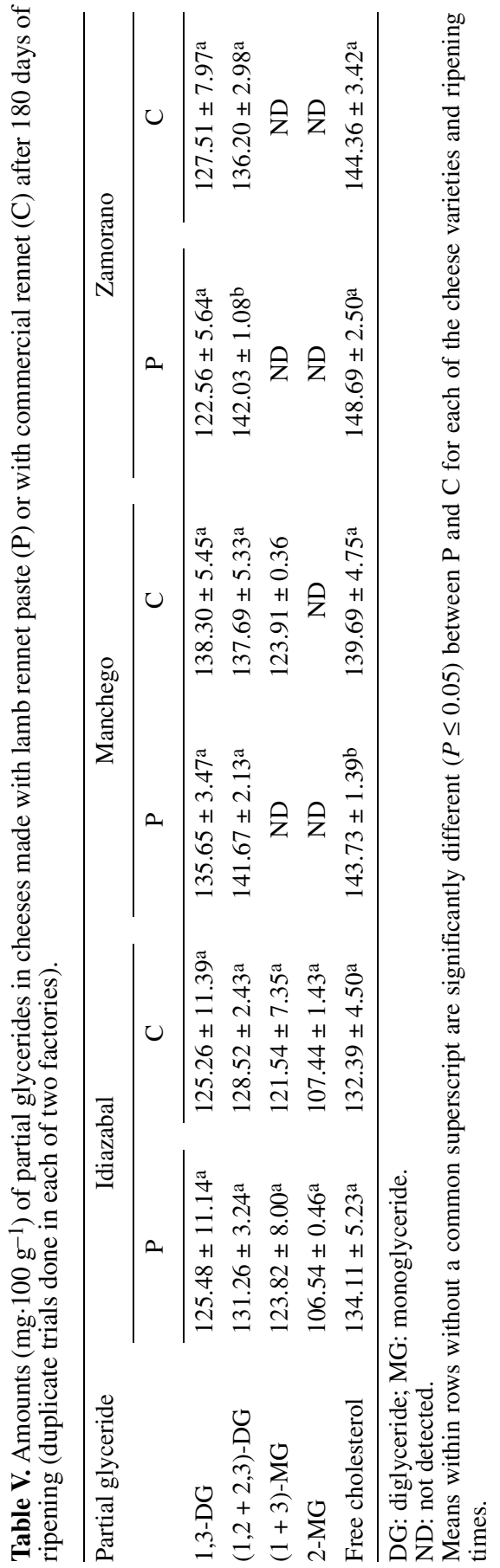



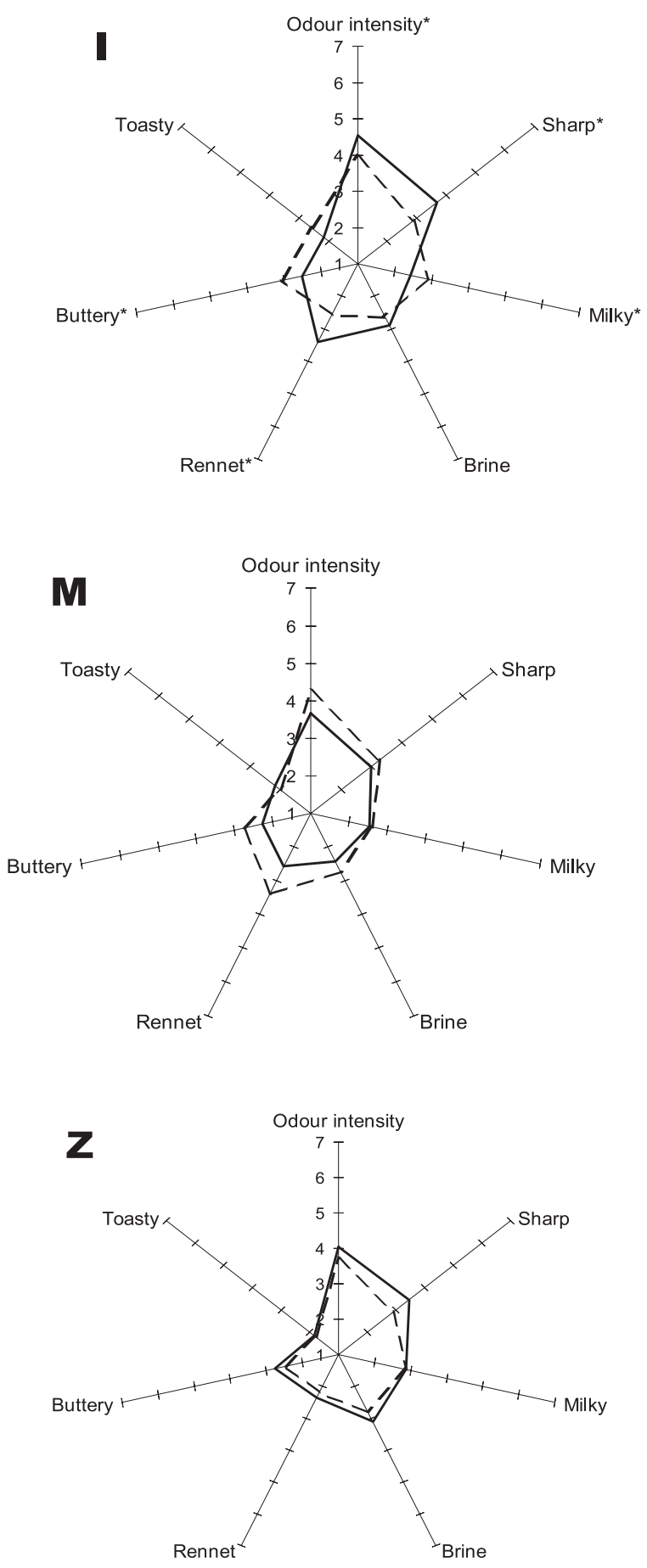

Figure 3. Odour profiles of Idiazabal (I), Manchego (M) and Zamorano (Z) cheeses after 180 days of ripening. Attributes marked with "**" have significantly different means $(P \leq 0.05)$ between cheeses made with lamb rennet paste and cheeses made with commercial rennet.

Continuous line: cheeses made with lamb rennet paste; discontinuous line: cheeses made with commercial rennet. 

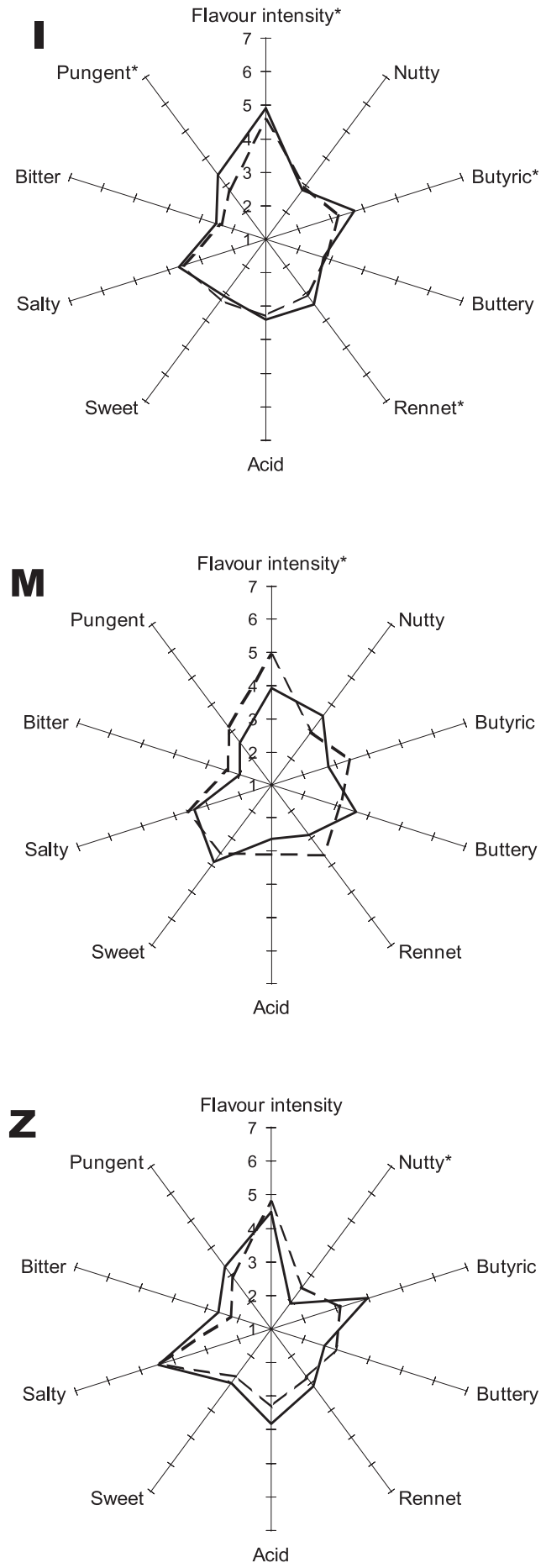

Figure 4. Flavour profiles of Idiazabal (I), Manchego (M) and Zamorano (Z) cheeses after 180 days of ripening. Attributes marked with "**" have significantly different means $(P \leq 0.05)$ between cheeses made with lamb rennet paste and cheeses made with commercial rennet.

Continuous line: cheeses made with lamb rennet paste; discontinuous line: cheeses made with commercial rennet. 
odour, in agreement with the data reported by Virto et al. [57] and Barron et al. [12]. In contrast, in Manchego and Zamorano cheeses only two attributes (flavour intensity and nutty flavour) were significantly different $(P \leq 0.05)$ between cheeses made with lamb rennet paste and cheeses made with commercial rennet. These results were totally unexpected because lipase-containing (lamb or kid) rennet pastes do impart a characteristic "piquant" taste to wellknown cheeses, such as Provolone and Romano cheese [16], Feta cheese [6] and the Idiazabal cheese $[12,35,57]$ which was included in this study as a cheese reference.

In order to increase the perceived intensity of the "piquant" taste in Manchego or Zamorano cheeses higher amounts of lipase should be added. In addition, considering the differences reported herein in the lipolytic parameters (total amount of FFA, percent FFA composition and total amounts of different partial glycerides), it could be reasonable to think that interactions among them could affect the intensity of the perceived individual attributes, resulting in practically no sensory differences between Manchego and Zamorano cheeses manufactured with either lamb rennet paste or commercial rennet. It is possible that in Manchego and Zamorano cheeses higher amounts of lipase than in Idiazabal cheese should be added in order to increase the intensity of the piquant taste.

\section{CONCLUSION}

Although the counts for some microorganisms in lamb rennet paste were higher than allowed by the current Spanish legislation, its use in cheese manufacture did not compromise the microbiological quality of the cheeses. These results argue in favour of the absence of a specific sanitary risk for using lamb rennet pastes in cheese manufacture and, in consequence, it appears that the current Spanish legislation could be revised to permit the commercialisation of lamb rennet pastes. Also, a common European legislation could be necessary to regulate the use of coagulants in the cheese industry. This work shows that the effect of adding lipase-containing lamb rennet paste depends on the cheese variety.

Acknowledgements: The authors thank M. Marquínez for excellent technical assistance and cheesemasters, J.P. Larrea (Quesería Gomiztegi, Arantzazu, Gipuzkoa, Spain), A. Segurola (Quesería Erreizabal, Legazpi, Gipuzkoa, Spain), F. Vicente (Quesería Vicente Pastor, Morales del Vino, Zamora, Spain), A. Santos de Pedro (Quesos Fariza, Fariza de Sayago, Zamora, Spain) and A. Piqueras (Quesería El Jarón, Valdepeñas, Ciudad Real, Spain) for making all the cheeses included in this study. The authors thank the Laboratorio Interprofesional Lácteo de Castilla y León (Palencia, Spain) and the Laboratorio de la Fundación de la Denominación de Origen Queso Manchego (Valdepeñas, Ciudad Real, Spain) for the analysis of the milk used for making Zamorano and Manchego cheeses, respectively, and the collaboration of the Regulatory Councils of the Idiazabal, Manchego and Zamorano Protected Designation of Origin. I. Etayo acknowledges a predoctoral fellowship from the Spanish Ministry of Education and M.S. Conde acknowledges a predoctoral fellowship from the Fundación Gangoiti (Bilbao, Spain). Financial support was provided by grants from the Spanish Ministry of Science and Technology (AGL2000-1029-C03-01) and the Universidad del País Vasco / Euskal Herriko Unibertsitatea (9/UPV 00042.125-1531/2003).

\section{REFERENCES}

[1] Addis M., Piredda G., Pes M., Di Salvo R., Scintu M.F., Pirisi A., Effect of the use of three different lamb paste rennets on lipolysis of the PDO Pecorino Romano Cheese, Int. Dairy J. 15 (2005) 563-569.

[2] Addis M., Pirisi A., Di Salvo R., Podda F., Piredda G., The influence of the enzymatic composition of lamb rennet paste on some properties of experimentally produced PDO Fiore Sardo cheese, Int. Dairy J. 15 (2005) 1271-1278.

[3] AENOR, Análisis sensorial. Guía para la instalación de una sala de cata. UNE 87-004, Asociación Española de Normalización, Madrid, Spain, 1979.

[4] AENOR, Microbiología - Recuento de estafilococos coagulasa positivo (Staphylococcus aureus y otras especies). Parte 2. Técnica que utiliza el medio del agar de plasma de conejo y fibrinógeno. UNE-EN ISO 6888-2, Asociación 
Española de Normalización, Madrid, Spain, 2000.

[5] AFNOR, Directives générales pour le dénombrement des coliformes fécaux et d'Escherichia coli, AFNOR NF V08 017, Association Française de Normalisation, Paris, France, 1999.

[6] Anifantakis E., Influence d'une présure d'agneau sur la qualité du fromage Kefalotyri, Lait 56 (1976) 76-83.

[7] Anifantakis E., Green M.L., Preparation and properties of rennets from lamb's and kid's abomasa, J. Dairy Res. 47 (1980) 221-230.

[8] Bárcenas P., Pérez-Elortondo F.J., Salmerón J., Albisu M., Development of a preliminary sensory lexicon and standard references of ewes milk cheeses aided by multivariate statistical procedures, J. Sens. Stud. 14 (1999) 161-179.

[9] Bárcenas P., Pérez-Elortondo F.J., Albisu M., Selection and screening of a descriptive panel for ewes milk cheese sensory profiling, J. Sens. Stud. 15 (2000) 79-99.

[10] Bárcenas P., Pérez-Elortondo F.J., Salmerón J., Albisu M., Sensory profile of ewe's milk cheeses, J. Food Sci. Technol. Int. 7 (2001) 347-353.

[11] Barrios M.J., Estudio micotoxicológico de quesos de España (región sur), Tesis doctoral, Facultad de Veterinaria, Universidad de Córdoba, Spain, 1994.

[12] Barron L.J.R., Hernández I., Bilbao A., Flanagan C.E., Nájera A.I., Virto M., PérezElortondo F.J., Albisu M., de Renobales M. Changes in lipid fractions and sensory properties of Idiazabal cheese induced by lipase addition, J. Dairy Res. 71 (2004) 372-379.

[13] Barron L.J.R., Redondo Y., Flanagan C.E., Pérez-Elortondo F.J., Albisu M., Nájera A.I., de Renobales M., Fernández-García E., Comparison of the volatile composition and sensory characteristics of Spanish PDO cheeses manufactured from ewe's raw milk and animal rennet, Int. Dairy J. 15 (2005) 371382.

[14] Barton R.H., O’Connor C.J., Turner K.W., Characteristics of tributyroylglycerol hydrolysis mediated by a partially purified lamb pregastric lipase, J. Dairy Sci. 79 (1996) 27-32.

[15] Barzaghi S., Davoli E., Rampilli M., Contarini G., La lipolisi nel formaggio Provolone: ruolo del caglio in pasta, Sci. Tec. Latt.Casearia 48 (1997) 146-156.

[16] Battistotti B., Corradini C., Italian cheese, in: Fox P.F. (Ed.), Cheese: chemistry, physics and microbiology, vol. 2, 2nd edn., Chapman and Hall, London, UK, 1993, pp. 221-243.
[17] Berdagué J.L., Grappin R., Affinage et qualité du Gruyère de Comté. II. Influence de l'affinage sur l'évolution des caractéristiques physico-chimiques des fromages, Lait 67 (1987) 237-241.

[18] Bérodier F., Lavanchy P., Zannoni M., Casals J., Herrero L., Adamo C., A guide to the sensory evaluation of smell, aroma and taste of hard and semihard cheeses, Lebensm.-Wiss. Technol. 30 (1997) 653664.

[19] BOE, Orden de 14 de enero de 1988, de los Ministerios de Sanidad y Consumo y Hacienda y de Agricultura, Pesca y Alimentación por la que se aprueba la "Norma general de identidad y pureza para el cuajo y otras enzimas coagulantes de leche destinadas al mercado interior", Boletín Oficial del Estado de 20 de enero de 1988, Madrid, Spain, 1988.

[20] BOE, Orden de 6 de mayo de 1993 del Ministerio de Agricultura, Pesca y Alimentación, por la que se aprueba el "Reglamento de la Denominación de Origen Queso Zamorano y de su Consejo Regulador", Boletín Oficial del Estado de 20 de mayo de 1993, Madrid, Spain, 1993.

[21] BOE, Orden de 30 de noviembre de 1993 del Ministerio de Agricultura, Pesca y Alimentación, por la que se aprueba el "Reglamento de la Denominación de Origen Idiazabal y su Consejo Regulador", Boletín Oficial del Estado de 3 de diciembre de 1993, Madrid, Spain, 1993.

[22] BOE, Orden de 23 de noviembre de 1995 del Ministerio de Agricultura, Pesca y Alimentación, por la que se ratifica el "Reglamento de la Denominación de Origen Queso Manchego y de su Consejo Regulador", Boletín Oficial del Estado de 11 de diciembre de 1995, Madrid, Spain, 1995.

[23] Bustamante M., Chavarri F., Santisteban A., Ceballos G., Hernández I., Mígueles M.J., Aranburu I., Barron L.J.R., Virto M., de Renobales M., Coagulating and lipolytic activities of artisanal lamb rennet pastes, J. Dairy Res. 67 (2000) 393-402.

[24] Bustamante M.A., Virto M., Aramburu M., Barron L.J.R., Pérez-Elortondo F.J., Albisu M., de Renobales M., Lamb rennet paste in ovine cheese (Idiazabal) manufacture. Proteolysis and relationship between analytical and sensory parameters, Int. Dairy J. 13 (2003) 547-557.

[25] Calandrelli M., Rubino R., Masoero G., Clementi F., Morone G., Pizzillo M., Nicastro D., Effect of kid rennet production technology on its microbiological characteristics and on the chemical composition of Semicotto goat 
cheese, Sci. Tec. Latt.-Casearia 48 (1997) 343-360.

[26] Calvo M.V., Fontecha J., Purification and characterization of a pregastric esterase from a hygienized kid rennet paste, J. Dairy Sci. 87 (2004) 1132-1142.

[27] Chavarri F., Virto M., Martín C., Nájera A.I., Santisteban A., Barron L.J.R., de Renobales M., Determination of free fatty acids in cheese: comparison of two analytical methods, J. Dairy Sci. 64 (1997) 445-452.

[28] Collins Y.F., McSweeney P.L.H., Wilkinson M.G., Lipolysis and free fatty acid catabolism in cheese: a review of current knowledge, Int. Dairy J. 13 (2003) 841-866.

[29] De la Fuente M., Fontecha J., Juárez M., Fatty acid composition of the triglyceride and free fatty acid fractions in different cows-, ewesand goats-milk cheeses, Z. Lebensm. Unters. Forsch. 196 (1993) 155-158.

[30] Deeth H.C., Fitz-Gerald C.H., Lipolytic enzymes and hydrolytic rancidity in milk and milk products, in: Fox P.F. (Ed.), Developments in dairy chemistry, vol. 2, Elsevier Applied Science Publishers, London, UK, 1983, pp. 195-239.

[31] DOCE, Directiva 94/71/CE del Consejo de 13 de diciembre de 1994 por la que se modifica la Directiva 92/46/CEE por la que se establecen las "Normas sanitarias aplicables a la producción y comercialización de leche cruda, leche tratada térmicamente y productos lácteos", Diario Oficial de las Comunidades Europeas, Brussels, Belgium, 1994.

[32] Fontecha J., Goudjil H., Ríos J.J., Fraga M.J., Juárez M., Identity of the major triacylglycerols in ovine milk fat, Int. Dairy J. 15 (2005) 1217-1224.

[33] Fox P.F., McSweeney P.H.L., Rennets: their role in milk coagulation and cheese ripening, in Law B.A. (Ed.), Microbiology and Biochemistry of Cheese and Fermented Milk, 2nd edn., Chapman and Hall, London, UK, 1997, pp. 1-49.

[34] Ghandi N.N., Applications lipase, J. Am. Oil Chem. Soc. 74 (2005) 621-634.

[35] Hernández I., de Renobales M., Virto M., Pérez-Elortondo F.J., Barron L.J.R., Flanagan C., Albisu M., Assessment of industrial lipases for flavour development in commercial Idiazabal (ewe's raw milk) cheese, Enzyme Microbiol. Technol. 36 (2005) 870879.

[36] Herrero L., Denominaciones de origen de quesos de España, in: Jornadas Técnicas del
Comité Plenario de la Red de Villas Europeas Unidas por el Queso, 31 de marzo y 1 de abril de 2005, Ordizia, Spain, 2005, pp. 1-22.

[37] IDF, Protein content of processed cheese products. IDF Standard 25, Int. Dairy Fed., Brussels, Belgium, 1964.

[38] IDF, Cheese and Processed cheese. Determination of the total solids content (Reference Method). Provisional IDF Standard 4A: 1982, Int. Dairy Fed., Brussels, Belgium, 1982.

[39] IDF, Determination of the clotting time of milk to which a milk-clotting enzyme solution has been added. IDF Standard 110A: Appendix A, Int. Dairy Fed, Brussels, Belgium, 1987.

[40] IDF, Milk and milk products. Preparation of test samples and dilutions for microbiological examination. IDF Standard 122B, Int. Dairy Fed, Brussels, Belgium, 1992.

[41] ISO, Cheese. Determination of fat content. Butyrometer for Van Gulik method. ISO 3432, International Organization for Standardization, Geneva, Switzerland, 1975.

[42] ISO, Horizontal method for the detection and enumeration of Listeria monocytogenes. Part 1: Detection method. ISO 11290-1, International Organization for Standardization, Geneva, Switzerland, 1998.

[43] Irigoyen A., Izco J.M., Ibáñez F.C., Torre P., Influence of rennet milk-clotting activity on the proteolytic and sensory characteristics of an ovine cheese, Food Chem. 72 (2001) 137144.

[44] Kalantzopoulos G.C., Cheeses from ewe's and goats' milk, in: Fox P.F. (Ed.), Cheese: chemistry, physics and microbiology, vol. 2, 2nd edn., Chapman and Hall, London, UK, 1993, pp. 507-553.

[45] Lai D.T., MacKenzie A.D., O’Connor C.J., Turner K.W., Hydrolysis characteristics of bovine milk fat and monoacid triglycerides mediated by pregastric lipase from goats and kids, J. Dairy Sci. 80 (1997) 2249-2257.

[46] Lavanchy P., Bérodier F., Zannoni M., Noël Y., Adamo C., Squella J., Herrero L., L'évaluation sensorielle de la texture des fromages à pâte dure ou semi-dure. Étude interlaboratoires, Lebensm-Wiss. Technol. 26 (1993) $59-68$.

[47] Moatsou G., Moschopoulou E., Georgala A., Zoidou E., Kandarakis I., Kaminarides S., Anifantakis E., Effect of artisanal liquid rennet from kids and lambs abomasa on the characteristics of Feta cheese, Food Chem. 88 (2004) 517-525.

[48] Moskowitz G.J., Noelck S.S., Enzyme-modified cheese technology, J. Dairy Sci. 70 (1987) 1761-1769. 
[49] Muir D.D., Hunter E.A., Sensory evaluation of Cheddar cheese: order of tasting and carryover effects, Food Qual. Prefer. 3 (1991/2) 141-145.

[50] Nájera A.I., Barron L.J.R., Barcina Y., Changes in free fatty acids during the ripening of Idiazabal cheese: influence of brining time and smoking, J. Dairy Res. 61 (1994) 281-288.

[51] Parodi P.W., Positional distribution of fatty acids in the triglyceride classes of milk fat, J. Dairy Res. 49 (1982) 73-80.

[52] Pascual M.R., Calderón V., Microbiología alimentaria. Metodología analítica para alimentos y bebidas, Editorial Díaz de Santos, Madrid, Spain, 1999.

[53] Pérez-Elortondo F.J., Albisu M., Barcina Y., Physicochemical properties and secondary microflora variability in the manufacture and ripening of Idiazabal cheese, Lait 79 (1999) 281-290.

[54] Pinna G., Pirisi A., Piredda G., Addis M., Di Salvo R., Effetto della termizzazione del latte sul formaggio DOP Fiore Sardo: 2. Andamento della lipolisi nel corso della maturazione, Sci. Tec. Latt.-Casearia 50 (1999) 366-377.

[55] Stadhouders J., Veringa H.A., Fat hydrolysis by lactic acid bacteria in cheese, Neth. Milk Dairy J. 27 (1973) 77-91.

[56] Svensson I., Hernández I., Virto M., de Renobales M., Determination of lipase activity in cheese using trivalerin as substrate, Int. Dairy J. 16 (2006) 423-430.

[57] Virto M., Chávarri F., Bustamante M.A., Barron L.J.R., Aramburu M., Vicente M.S. Pérez-Elortondo F.J., Albisu M., de Renobales M., Lamb rennet paste in o vine cheese manufacture. Lipolysis and flavour, Int. Dairy J. 13 (2003) 391-399.

[58] Wigley R.C., Cheese and whey, in: Godfrey T., West S. (Eds.), Industrial Enzymology, Macmillan, London, UK, 1996, pp 133-154. 